University of Nebraska - Lincoln

DigitalCommons@University of Nebraska - Lincoln

Faculty Publications from the Harold W. Manter Laboratory of Parasitology

6-1969

Pythonella scelopori sp. n. (Protozoa: Eimeriidae) from a Costa Rican Lizard

Donald W. Duszynski

University of New Mexico, eimeria@unm.edu

Follow this and additional works at: https://digitalcommons.unl.edu/parasitologyfacpubs

Part of the Parasitology Commons

Duszynski, Donald W., "Pythonella scelopori sp. n. (Protozoa: Eimeriidae) from a Costa Rican Lizard" (1969). Faculty Publications from the Harold W. Manter Laboratory of Parasitology. 116.

https://digitalcommons.unl.edu/parasitologyfacpubs/116

This Article is brought to you for free and open access by the Parasitology, Harold W. Manter Laboratory of at DigitalCommons@University of Nebraska - Lincoln. It has been accepted for inclusion in Faculty Publications from the Harold W. Manter Laboratory of Parasitology by an authorized administrator of DigitalCommons@University of Nebraska - Lincoln. 


\section{Pythonella scelopori sp. n. (Protozoa: Eimeriidae) from a Costa Rican Lizard}

Colon contents from 33 lizards collected in Costa Rica during July and August 1967 were preserved in $2 \%$ aqueous potassium dichromate solution. Subsequent examination of the preserved fecal material from 17 Ctenosaura similis, 5 Basiliscus basiliscus, 5 Ameiva leptophrys, 3 A. undulata, 1 A. quadralineata, 1 Sceloporus squamosus, and $1 \mathrm{~S}$. variabilis revealed a species of Pythonella in the only S. squamosus examined.

Pythonella is characterized by an oocyst containing 16 sporocysts each with four sporozoites. Previously a monotypic genus containing $P$. bengalensis, it was described from a Python sp. in India by Ray and Das-Gupta (1937, Indian Sci. Cong. Proc. 24: 292). Their description listed only oocyst diameter ( 25 to $30 \mu$ ) and sporocyst length and width ( 8 to 10 by $6.7 \mu$ ) with limited information on some endogenous stages. No figure was presented in the original description.

Since only nine oocysts were observed in the small amount of fecal material collected, the measurements for all oocysts are presented below. All measurements are in microns, with means given in parentheses following the range.

\section{Pythonella scelopori sp. $\mathbf{n}$.}

(Figs. 1-5)

Morphology: Unsporulated oocysts (Fig. 1) ovoid with colorless, smooth outer wall of uniform thickness. Micropyle absent. Wall thickness less than 1; composed of a single layer. Unsporulated oocysts $(N=4) 33$ to 40 by 25 to 34 ( 36.0 by 28.9 ). Shape index 1.16 to 1.33 (1.25). Sporulated oocysts (Figs. 3, 5) broadly ovoid with colorless outer wall of uneven thickness due to distortion by tightly packed sporocysts. Wall thickness less than 1 ; composed of single layer. Micropyle absent. Sporulated oocysts $(N=4)$ 41 to 48 by 29 to 33 ( 43.7 by 31.4 ). Shape index 1.30 to 1.51 (1.39). Polar body apparently lacking. Oocyst residuum present as small granules scattered among sporocysts. Sporocysts round to slightly ovoid, but occasionally distorted due to tight packing in oocyst. Sporocysts $(N=25) 8$ to 10 by 7 to 9 ( 8.7 by 8.1 ). Shape index 1.00 to 1.28 (1.07). Stieda body lacking. Crescentshaped sporozoites (Fig. 4) 2 to 3 by 7 to 10 . Sporozoites without observable nucleus or refractile globules. Sporocyst residuum absent. One anomaly (Fig. 2) with 10 sporocysts measured 40.7 by 28.6 .
Sporulation time: Unknown. Preserved fecal material was carried through various tropical environments for 62 days as storage and temperature control equipment were not available. Upon return to the United States, the material was stored at $5 \mathrm{C}$ until examined.

Host: Sceloporus squamosus.

Location in host: Unknown; oocysts found in feces.

Locality: Playas Del Coco, Guanacaste, Costa Rica.

\section{Remarks}

Several coccidian genera contain species which have 16 or more sporocysts per oocyst. Of these, Cariniella, Klossia, and Orcheobius have sporocysts which vary in number from four to 160 per oocyst (Levine, Ivens, and Kruidenier, 1955, J. Parasit. 41: 623-629). Only Pythonella oocysts have been reported to contain exactly 16 sporocysts (Ray and DasGupta, loc. cit.), and although only four sporulated oocysts were observed, each contained 16 sporocysts. In addition, the former three genera have been reported primarily

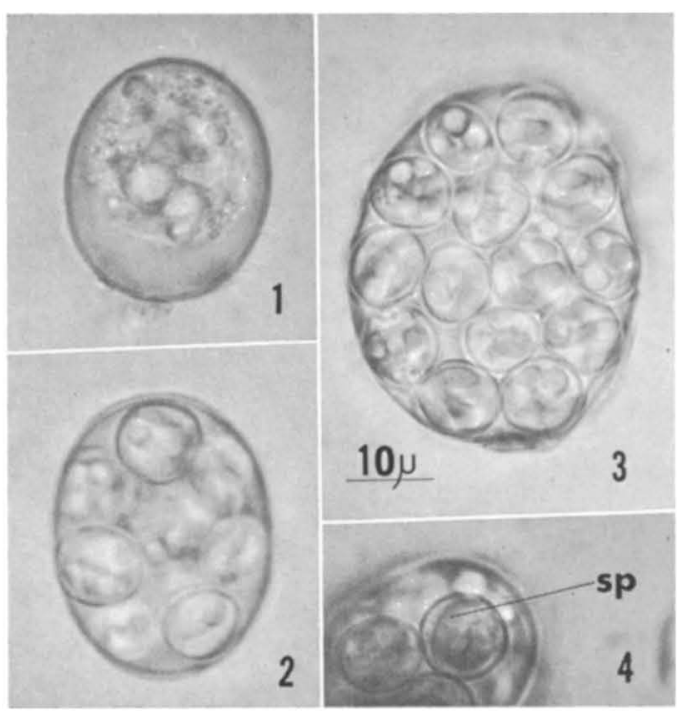

Figures 1-4. Pythonella scelopori sp. n. from Sceloporus squamosus in Costa Rica. 1. Unsporulated oocyst. 2. An anomaly with 10 sporocysts. Shape, size, and structure of contents indicate a variant of $P$. scelopori. 3. Sporulated oocyst with 14 of 16 sporocysts in focus. Note four sporozoites per sporocyst. 4. Sporocyst with one of its crescentshaped sporozoites ( $\mathrm{sp}$ ) in focus. 


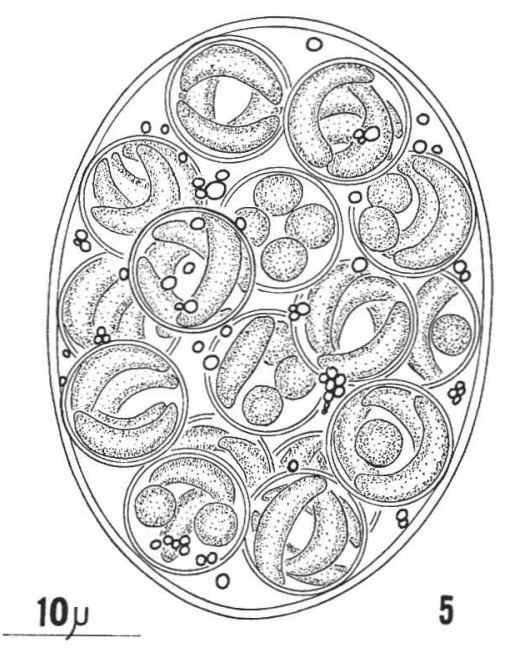

Figure 5. Sporulated oocyst of P. scelopori. Camera lucida drawing.

from invertebrate hosts (snails, leeches, earthworms), whereas Pythonella has been described from a reptile. Measurements of the sporulated oocysts observed in the present study do not fall into the range of $P$. benga- lensis. This information and the differences in hosts and continents indicate that the present organism is a new species.

Sceloporus squamosus is chiefly insectivorous, although stomach content analysis showed they also eat spiders and other arthropods, and it is possible that $P$. scelopori may actually be a parasite of an invertebrate eaten by the lizard. However, several of the sympatric species also examined, particularly $C$. similis and Ameiva spp., were also shown by stomach analysis to subsist on quite similar diets and in no instance were oocysts of Pythonella observed.

This study was supported, in part, by an NSFFord Foundation summer fellowship in conjunction with the Organization for Tropical Studies and, in part, by a Training Grant, No. 5T1 A1 94-08 from the NIAID, NIH, U. S. Public Health Service. I wish to thank Peter Eric Hillman, graduate student, Department of Zoology, Washington State University, Pullman, for aid in lizard identification.

Donald W. Duszynski, Department of Zoology, Colorado State University, Fort Collins, Colorado 80521 